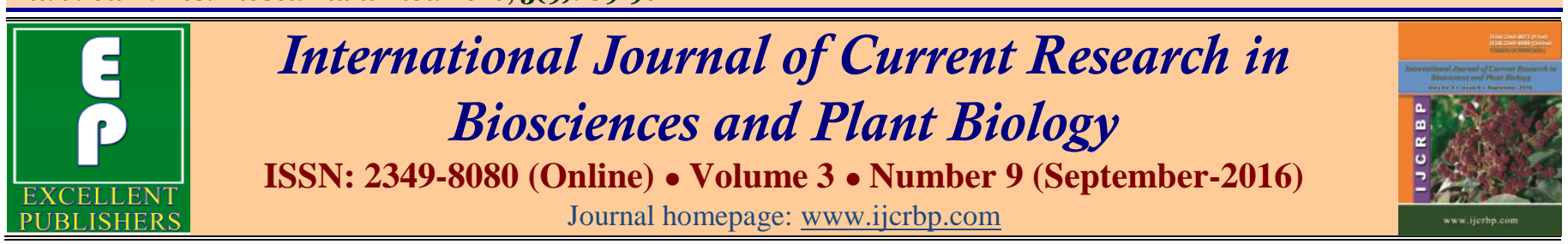

\title{
Improving Environmental and Economic Benefits through Zero-Tillage in Mirzapur District of Uttar Pradesh, India
}

\author{
O. P. Singh*, Rakesh Singh, Kerobim Lakra and P.K. Singh \\ Department of Agricultural Economics, Institute of Agricultural Sciences, Banaras Hindu University, Varanasi -221 oo5, \\ Uttar Pradesh, India
}

*Corresponding author.

\begin{abstract}
A b st ract
Resource Conservation Technologies (RCTs) is playing an important role in improving crop yield and reducing cost of cultivation on sustainable basis. Zero-tillage is one of the options of RCTs, under which farmer are sowing wheat crop using zero-tillage machine just after harvesting paddy crop without land preparation. Present study was an attempt to find out the impact of zero-tillage on farmer income and environmental benefits in Mirzapur district of Uttar Pradesh. The study was based on the primary data and it was collect through personal interview. Study revealed that education level of respondents, farming experience and land holding size were positive and significantly influencing factors responsible for adoption of zero-tillage in the study area. Per hectare cost of cultivation of wheat was reduced by Rs 7077 and yield was increased by 2.61 quintals for zero-tillage adopters as compared to non-adopters. After adoption of zero-tillage, per hectare carbon emission was reduced by $18.99 \mathrm{~kg}$. Therefore, government should encourage farmer to adopt zero-tillage for sowing of wheat crop by providing subsidy on the zero-tillage machine in the study area resulting into reduction in the charges of zero-tillage machine and availability of machine on time.
\end{abstract}

\author{
Article Info \\ Accepted: 30 August 2016 \\ Available Online: 06 September 2016

\section{Ke ywords} \\ Energy saving \\ Farmers' income \\ Logit model \\ Resource Conservation Technologies \\ Wheat \\ Zero tillage
}

\section{Introduction}

Traditionally, the tillage practice for wheat showed that there were over 5 ploughing with the country plough behind the bullock and over one or two planking to level the soil (Saunders, 1990; Meisner, 1992, 1996, 1999 and 2001). One of the transformations that are taking place in the cultivation of wheat crop in rice-wheat cropping system is the evolution of zero tillage technology and there is a paradigm shift from conventional to zero tillage. Zero-tillage is one of the options of Resource Conservation Technologies (RCTs) under which wheat seed and fertilizer are placed into the soil with the help of zero-tillage machine just after harvesting paddy crop without land preparation. Zero-tillage with crop residue management system provides permanent soil cover and minimum soil disturbance which helps farmers to minimise seasonal weed infestation in Indo-Gangetic Plain. It has been realized that benefits of RCTs can be further improved by adopting remunerative cropping system/catch crop (Singh et al., 2005). The potential benefits of zero tillage are early planting, greater efficiency and less maintenance costs of machinery, more time for management decisions and technical upgrading, less dusty and muddy work environment, more time for family, less stress and greater satisfaction derived from caring for the environment. Gentil (1995) reported that after adoption of zero-tillage, diesel fuel consumption for land preparation and sowing of wheat crop was reduced by 50 to 70 per cent, or more and proportional reductions in greenhouse gas emissions. Zero tillage per se has a major impact in reducing carbon 
dioxide emissions when compared to conventional tillage, by immobilizing carbon in incremental soil organic matter and surface residues (Derpsch, 1998).

Looking the benefits of zero tillage an attempt has been made to analyse the environmental and economic benefit of zero-tillage in Mirzapur district of Uttar Pradesh. The specific objective of the present study were: [a] to compare the cost of cultivation of wheat under zerotillage and conventional method; [b] to analyse the economic and environmental benefit of zero- tillage; [c] to determine the relative importance of various factors influencing adoption of zero-tillage; and [d] to find out the constraints associated with adoption of zero- tillage.

\section{Materials and methods}

\section{Sampling procedure}

The Vindhyan agro-climatic zone of Uttar Pradesh consists of four districts viz., Allahabad, Sant Ravidas Nagar, Mirzapur and Sonbhdra. Out of these districts, Mirzapur district was purposively selected on the basis of highest adoption of zero-tillage. Out of twelve development blocks, two development blocks viz., Narayanpur and Jamalpur was selected purposively on the basis of highest and lowest adoption of zero-tillage, respectively. From selected development block, Pirkhir village from Jamalpur and Bhurkura village from Narayanpur development block was selected purposively on the basis of availability of zero-tillage adopters and non-adopters. From each village, 10 zero-tillage adopters and 10 non-adopters were selected using snowball sampling method. Thus, altogether, 40 respondents were finally selected from two villages.

\section{Analytical procedure}

\section{Cost of cultivation}

For the estimation of cost of cultivation of wheat crop under conventional and zero- tillage was calculated by using methodology developed by the Commission for Agricultural Cost and Prices (CACP). The different cost was calculated as:

Cost $A_{1}$ : All the input cost + depreciation on implements and farm buildings+ land revenue, cesses and other taxes+ interest on working capital+ miscellaneous expenses

Cost $B_{1}$ : Cost $A_{1}+$ interest on value of owned fixed capital assets (excluding land)

Cost $C_{1}$ : Cost $B_{1}+$ rental value of owned land+ rent paid for leased-in land

Cost $C_{2}$ : Cost $C_{1}+$ imputed value of family labour

Cost $\mathrm{C}_{3}$ : Cost $\mathrm{C}_{2}+10$ percent of $\cos \mathrm{C}_{2}$ as account for managerial input of the farmer

\section{Economic and environment benefits}

The economic benefits of $\mathrm{RCT}_{\mathrm{S}}$ was worked out using economic surplus model as suggested by the Alston et al.(2005).The model is given below:

$$
\begin{aligned}
& \triangle C S=P Q Z(1+0.5 Z n) \\
& \triangle P S=P Q(K-Z)(1+0.5 Z \eta) \\
& \triangle T S=\Delta C S+\triangle P S=P Q K(1+0.5 Z \eta)
\end{aligned}
$$

Where $\mathrm{Z}=\mathrm{K} \varepsilon /(\varepsilon+\eta)$; $\mathrm{K}$ is vertical shift in supply function as proportion of initial price; $\eta$ is elasticity of demand (absolute); and $\varepsilon$ is elasticity of supply.

The environmental benefits realized by adoption of zero tillage are reduction in carbon emission. To find out the reduction of carbon emission, first of all diesel saving on farm operations was quantified and multiplied by the one litre equal to $2.6 \mathrm{~kg}$ of $\mathrm{CO}_{2}$ (Jat et al., 2006) and one $\mathrm{kg}$ $\mathrm{CO}_{2}$ is $0.27 \mathrm{~kg}$ of carbon (Paustian et al., 2006).

Irrigation water saving is also an environmental benefit. The farmer of the study area was using groundwater for irrigating wheat crop. For the quantification of irrigation water used for irrigation purposes, following formula was used:

$$
P d_{\left(m^{\mathrm{g}} / H r\right)}=\frac{H P x 75 \times P_{e}}{1000 \times D W} \times 3600
$$

Where: $\mathrm{Pd}$ is pump discharge rate measured in $\mathrm{m}^{3}$ per hour; HP is the pump capacity; $\mathrm{Pe}$ is the pump efficiency; and DW is depth to water level plus head of delivery pipe measured in meter. 


\section{Factors Influencing adoption of zero-tillage}

For identification of relative importance of various factors influencing adoption of $\mathrm{RCT}_{\mathrm{S}}$ in different Agroclimatic zone was worked out by using binary logit model (Mallada, 1992). The algebraic form of model is given below:

$$
p_{i}=\frac{1}{1+e^{-Z_{i}}}
$$

Where, $p_{i}$ is a probability of adoption of conservation tillage technology for the $\mathrm{i}^{\text {th }}$ farmer and ranges from 0 to 1. $\mathrm{e}^{-\mathrm{Z}}$ represents the base of natural logarithms and $Z_{\mathrm{i}}$ is the function of a vector of $n$ explanatory variables and expressed as follows.

$$
Z_{i}=\beta_{0}+\sum \beta_{i} X_{i}
$$

Where, $\beta_{0}$ is the intercept and $\beta_{\mathrm{i}}$ is a vector of the relationship between $p_{i}$ and $X_{i}$, which is non-linear, can be written as follows:

$$
p_{i}=\frac{1}{1+e^{-\left(\beta_{0}+\beta_{1} x_{i} \ldots \beta_{n} x_{n}\right)}}
$$

Finally, the logit model is obtained by using the logarithm

$$
L_{i}=L_{n}\left[\frac{p_{i}}{1-p_{i}}\right]=z_{i}=\beta_{0}+\beta_{1} x_{1}+\beta_{2} x_{2}+\ldots . .+\beta_{n} x_{n}
$$

\section{Identification of constraints}

The Garret Ranking was used to rank the constraints associated with the zero tillage adoption. The percentage of each rank thus obtained was converted into scores by referring to the table given by Henry Garret. The score of all the factors were arranged in order of their ranks.

$$
\text { Percent Position }=\frac{100\left(R_{i j}-0.5\right)}{N_{j}}
$$

Where, $R_{i j}$ is the rank given for $i^{\text {th }}$ item $j^{\text {th }}$ individual and $\mathrm{N}_{\mathrm{j}}$ is the number of items ranked by $\mathrm{j}^{\text {th }}$ individuals.

\section{Results and discussion}

\section{Factors influencing adoption of zero-tillage}

A binary logit analysis was undertaken to determine quantitatively how the relevant factors interact to influence farmers in their adoption of zero-tillage. The regression results depicts that the likelihood ratios that are considerably high and significant at 5 per cent level, thus the model in general explained factors associated with the adoption of RCTs. The Nagelkerke $\mathrm{R}^{2}$ values are ranged from 0 to 1 and it is a more reliable measure of the relationship (Table 1). In the model it was 0.375 , indicates a fair relationship of 37.5 per cent between the predictors and the prediction. Among the explanatory variables used in the model, three variables were significant with respect to adoption of zero-tillage with 10 per cent of the probability level. Result shows that the education level of the farmers, farming experience and land holding size of the farmers has positive and significant impact on the adoption of zero- tillage in the study area. This implies that as farming experience, education level and land holding size increases, there is higher probability of adopting zero-tillage in the study area (Singh et al., 2011).

Beside above variables, one of the important influencing factors for adoption of zero-tillage in the study area was soil type. Type of soil found in the study area is mostly black soil and property of soil is higher water retention capacity which takes relatively more times to dry up. So in this condition the zero-tillage machine can be easily used for the sowing of wheat crop.

\section{Cost of cultivation of wheat crop}

Per hectare cost of cultivation of wheat for zero-tillage adopters and non adopters was estimated to be Rs 51361.65 and Rs 58438.73 for zero-tillage adopters and non-adopters respectively (Table 2). Among the different inputs used, zero-tillage adopters were spending less money on machine labour, seed, fertilizer, irrigation and harvesting as compared to non-adopters. In case of zerotillage adopters, the share of expenditure on human labour, machine labour, seed, fertiliser, irrigation was estimated to be 5.33, 4.06, 6.68, 8.88 and 10.83 per cent of total cost of cultivation of wheat crop respectively, whereas in case of non-adopters, it was 7.01, 8.78, 7.40, 8.76 and 10.49 per cent of total cost of cultivation on human labour, machine labour, seed, fertiliser, irrigation respectively (Table 2). It was clear from the above discussion that zero-tillage adopters were using less inputs for crop production as compared to the non-adopters. 
Table 1. Factors influencing adoption of zero-tillage.

\begin{tabular}{|c|c|c|c|c|c|}
\hline Variables & $\mathbf{B}$ & S.E. & Wald & Sig. & $\operatorname{Exp}(B)$ \\
\hline a. Constant “a” & $-6.652 *$ & 3.027 & 4.828 & .028 & .001 \\
\hline b. Year of education of respondents & $0.356^{*}$ & .176 & 4.078 & .043 & 1.428 \\
\hline c. Farming experience (Year) & $0.126 * *$ & .072 & 3.079 & .079 & 1.135 \\
\hline e. Age of respondents (Year) & -1.277 & 1.231 & 1.076 & .300 & .279 \\
\hline f. Family size of respondent (No.) & -0.114 & .123 & .858 & .354 & .892 \\
\hline \multicolumn{6}{|l|}{ Model Summery } \\
\hline Cox \& Snell R Square & 0.282 & & & & \\
\hline Nagelkerke R Square & 0.375 & & & & \\
\hline
\end{tabular}

Table 2. Cost of cultivation of wheat crop.

\begin{tabular}{|c|c|c|c|c|c|c|}
\hline \multirow[b]{2}{*}{ Particulars } & \multicolumn{3}{|c|}{ Zero-tillage Adopters } & \multicolumn{3}{|c|}{ Zero-tillage Non-adopters } \\
\hline & $\begin{array}{l}\text { Physical } \\
\text { Unit }\end{array}$ & $\begin{array}{l}\text { Amount } \\
\text { (Rs.) }\end{array}$ & $\begin{array}{l}\% \text { to } \\
\text { Cost } \mathrm{C}_{3}\end{array}$ & $\begin{array}{l}\text { Physical } \\
\text { Unit }\end{array}$ & $\begin{array}{l}\text { Amount } \\
\text { (Rs.) }\end{array}$ & $\begin{array}{l}\% \text { to } \\
\text { Cost } \mathrm{C}_{3}\end{array}$ \\
\hline \multicolumn{7}{|l|}{ 1. Human labour } \\
\hline a. Family labour - Male & 5.82 & 1163.67 & 2.27 & 7.43 & 1486.84 & 2.54 \\
\hline b. Hired labour - Male & 7.67 & 1534.76 & 2.99 & 11.23 & 2245.07 & 3.84 \\
\hline c. Hired labour - Female & 0.19 & 38.24 & 0.07 & 1.84 & 368.42 & 0.63 \\
\hline 4. Manure (Qts) & 0.83 & 247.68 & 0.48 & - & - & - \\
\hline \multicolumn{7}{|l|}{ 5. Chemical fertiliser } \\
\hline a. Nitrogen & 185.59 & 1299.12 & 2.53 & 236.18 & 1653.29 & 2.83 \\
\hline b. Prosthetic & 113.89 & 2733.37 & 5.32 & 114.97 & 2759.21 & 4.72 \\
\hline c. Potash & 28.92 & 462.69 & 0.90 & 24.67 & 394.74 & 0.68 \\
\hline 7. Irrigation (Hrs) & 37.07 & 5560.05 & 10.83 & 40.86 & 6129.03 & 10.49 \\
\hline 8. Harvesting and Threshing & & 4340.53 & 8.45 & & 4470.39 & 7.65 \\
\hline 9. Sub-Total & & 23266.03 & 45.30 & & 29590.45 & 50.64 \\
\hline 10. Interest on working capital @7\%/annum & & 814.31 & 1.59 & & 1035.67 & 1.77 \\
\hline 11. Total Working Capital & & 24080.34 & 46.88 & & 30626.12 & 52.41 \\
\hline 12. Land revenue & & 0.00 & 0.00 & & 0.00 & 0.00 \\
\hline 13. Rental value of own land & & 7602.33 & 14.80 & & 17226.56 & 29.48 \\
\hline 14. Rental Value of leased in land & & 15009.74 & 29.22 & & 5273.44 & 9.02 \\
\hline 15. Cost $A_{1}$ & & 22916.67 & 44.62 & & 29139.27 & 49.86 \\
\hline 16. Cost $\mathrm{B}_{1}$ & & 22916.67 & 44.62 & & 29139.27 & 49.86 \\
\hline 17. Cost $C_{1}$ & & 45528.74 & 88.64 & & 51639.27 & 88.36 \\
\hline
\end{tabular}

\section{Income from wheat crop}

Many past researchers reported that after adoption of zero-tillage, yield of wheat crop and net income have been increased (Laxmi et al., 2007; Kumar et al., 2005; Singh et al., 2011; Pal et al., 2010; Singh and Meena, 2013). Per hectare yield of main product of wheat was estimated to be 35.59 and 32.98 quintals for zero-tillage adopters and non-adopters respectively, whereas in case of by-products it was more or less same for both zero tillage adopters and non adopters (Table 3). The average market price of wheat grain and by-product received by the sample farmer was Rs 1377.50 and Rs 487.50 respectively. In case of zero-tillage adopter, per hectare gross and net income was estimated to be Rs 66154.55 and Rs 14791.90 respectively, whereas in 
case of non-adopter it was Rs 61461.97 and Rs 3023.24 respectively for gross and net income. The cost for wheat production was Rs 1443.23 and Rs 1772.11 per quintal for zero-tillage adopters and non-adopters respectively. The B-C ratio was found to be 1.29 and
1.05 for zero-tillage adopters and non-adopter respectively (Table 3). From above discussion it is clear that zero-tillage adopters were getting higher crop yield, gross and net income and $\mathrm{B}-\mathrm{C}$ ratio as compared to non-adopters.

Table 3. Wheat yield, gross and net income from wheat crop.

\begin{tabular}{lll}
\hline Particulars & Zero-tillage Adopters & Zero-tillage Non-Adopters \\
\hline Crop yield and price & & \\
Main product (Qt/Ha) & 35.59 & 32.98 \\
By-product (Qt/Ha) & 32.14 & 32.89 \\
Market price of Main product (Rs./Qt) & 1377.50 & 1377.50 \\
Market price of By-product (Rs./Qt) & 487.50 & 487.50 \\
Gross Income (Rs./Ha) & $\mathbf{6 6 1 5 3 . 5 5}$ & $\mathbf{6 1 4 6 1 . 9 7}$ \\
Net Income Over & & \\
Cost $A 1$ & $43236 . .88$ & 32322.69 \\
Cost $B 1$ & 43236.88 & 32322.69 \\
Cost $C 1$ & 20624.81 & 9822.69 \\
Cost $C 2$ & 19461.41 & 8335.85 \\
Cost $C 3$ & 14791.90 & 3023.24 \\
Cost of Production (Rs./Qt) & & \\
Cost $A 1$ & 643.94 & 883.62 \\
Cost $B 1$ & 643.94 & 883.62 \\
Cost $C 1$ & 1279.33 & 1565.92 \\
Cost $C 2$ & 1312.02 & 1611.01 \\
Cost $C 3$ & 1443.23 & 1772.11 \\
Output-Input Ratio Over & & \\
Cost $A 1$ & 2.89 & 2.11 \\
Cost $B 1$ & 2.89 & 2.11 \\
Cost $C 1$ & 1.45 & 1.19 \\
Cost $C 2$ & 1.42 & 1.16 \\
Cost $C 3$ & 1.29 & 1.05 \\
\hline
\end{tabular}

\section{Agronomic and economic benefits of zero-tillage}

The zero-tillage adopters in the study area were received incremental agronomic benefits for main and by-product of wheat crop viz., 2.61 and 2.25 quintal per hectare respectively (Table 4). From the earlier discussion (section 3.2 and Table 2) that after adoption of zero- tillage farmers are using less inputs for wheat production as compared to non-adopters. Resulting to this, zerotillage adopters were saving more money due to reduction in cost of inputs and higher crop yield. Per hectare economic benefits due to the adoption of zerotillage for wheat crop was Rs 12751.32 in the study area.

Table 4. Agronomic and economic benefits of zero-tillage.

\begin{tabular}{lll}
\hline S. No. & Particulars & Amount (Rs.) \\
\hline A. & Agronomic Benefit & 2.61 \\
& a. $\quad$ Yield of main product (Qt/ha) & 2.25 \\
B. & b. Yield of by-product (Qt/ha) & 1363.65 \\
& Economic Benefits & 3042.88 \\
a. $\quad$ Due to reduction in Labour & 893.73 \\
b. Due to reduction in Machine labour & 556.24 \\
c. $\quad$ Due to reduction in seed & 16.75 \\
d. Due to reduction in fertilizer & 568.98 \\
e. $\quad$ Due to reduction in pesticide & 129.87 \\
f. $\quad$ Due to reduction in irrigation & 4691.59 \\
g. Due to reduction in harvesting & 1487.63 \\
& h. Due to yield benefits & $\mathbf{1 2 7 5 1 . 3 2}$ \\
\hline
\end{tabular}




\section{Environment benefits of zero-tillage}

Past studies reported that after adoption of zero-tillage, farmers were using less mechanical power for land preparation and sowing of wheat crop, resulting less consumption of energy i.e. diesel and the reduction in diesel used vary from region to region (Laxmi et al., 2007; Pal et al., 2010). Per hectare average diesel consumption for land preparation and sowing of wheat crop in the study area was estimated to be 18.54 and 45.59 litres for zero- tillage adopters and non-adopters respectively (Table 5). The reduction in diesel consumption after adoption of zero tillage was estimated to be 27.05 litres per hectare. After adoption of zero tillage, per hectare $\mathrm{CO}_{2}$ emission was reduced by 18.99 $\mathrm{kg}$. From above discussion it is clear that zero-tillage method of sowing wheat crop is a green technology. The sample farmers of the study area were using groundwater to irrigate wheat crop. Per hectare irrigation water used by the zero-tillage adopters and non adopters was estimated to be 700.57 and $772.26 \mathrm{~m}^{3}$ respectively. After adoption of zero-tillage, per hectare irrigation water saved by the zero tillage adopters was estimated to be $71.69 \mathrm{~m}^{3}$.

Table 5. Environment benefits of zero-tillage.

\begin{tabular}{lll}
\hline \multirow{2}{*}{ Particulars } & Zero-tillage & Non-adopter \\
\cline { 2 - 3 } & Adopter & 45.59 \\
1. Diesel consumption $(\mathrm{Lts} / \mathrm{Ha})$ & 18.54 & 118.54 \\
2. $\mathrm{CO}_{2}$ emission $(\mathrm{Kg} / \mathrm{Ha})$ & 48.22 & 32.01 \\
c. Carbon emission $(\mathrm{Kg} / \mathrm{Ha})$ & 13.02 & \\
d. Reduction in carbon emission $(\mathrm{Kg} / \mathrm{Ha})$ & 18.99 & \\
\hline
\end{tabular}

\section{Constrains associated with zero-tillage adoption}

Zero tillage adopters are not free from impudence and several constraints associated to them are presented in Table 6. Out of several constraints associated with the adoption of zero-tillage in the study area was weed problem in the agricultural field followed by the poor quality of soil, non-availability of zero-tillage machine on hire basis, non-availability of machine on-time for sowing of wheat crop and cost of machine is very high. The other constraint faced by the adopters of zero-tillage in the study area were non-availability of credit facility, lack of financial support and less crop yield under zerotillage.

Table 6. Constrains associated with adoption of zero-tillage.

\begin{tabular}{llll}
\hline S. No. & Reasons for Non-adoption of RCTs & Garrett Score & Rank \\
\hline 1. & Weed problem & 73.25 & I \\
2. & Poor soil quality & 67.00 & II \\
3. & Non-availability of zero-tillage on hire basis & 59.05 & III \\
4. & Non-availability of zero-tillage on time & 54.50 & IV \\
5. & High cost of zero-tillage machine & 54.10 & VI \\
6. & Labour issues & 54.00 & VII \\
7. & Uncertainty of irrigation & 53.95 & VIII \\
8. & Not sure of profit & 51.75 & IX \\
9. & Upland field & 50.50 & X \\
10. & Does not own zero-tillage machine & 49.85 & XI \\
11. & Custom hiring of zero-tillage is high & 48.75 & XII \\
12. & Not sure about technology & 46.30 & XIII \\
13. & Low yield under zero-tillage & 42.15 & XIV \\
14. & Lack of financial support & 25.30 & XV \\
\hline
\end{tabular}

\section{Condition for adoption of zero-tillage}

The conditions for adoption of zero-tillage in Mirzapur district is presented in Table 7. The most important condition for adoption of zero-tillage in the study area was if farmers convinced about the yield benefit of zerotillage then they adopt it. The condition which ranked second and third for adoption of zero-tillage was availability of irrigation water and more observation about zero-tillage on other's field respectively. The least important condition for adoption of zero-tillage was nonavailability of skilled labour for operating zero-tillage machine and absence of better repair service available in the study area. 
Table 7. Condition for adoption of zero-tillage.

\begin{tabular}{llll}
\hline Sl. No. & Condition for adoption of RCTs & Garrett Score & Rank \\
\hline 1. & If convinced of yield benefit & 61.85 & I \\
2. & Irrigation water availability & 53.70 & II \\
3. & More observation on other field & 50.80 & III \\
4. & If ZT is available on subsidy & 50.15 & IV \\
5. & If custom hiring rate is low & 46.95 & V \\
6. & Non-availability of skilled labour & 43.40 & VI \\
7. & If better repair service is available & 42.25 & VII \\
\hline
\end{tabular}

\section{Conclusions and policy implications}

Zero tillage is one of the promising technologies that enhance wheat productivity, profitability and sustainability. The results suggest that adoption of zero-tillage was positively and significantly influenced by the education of farmers, farming experience and land holding size. The zero-tillage adopters saved machine hours for land preparation and sowing of wheat crop, low cost of cultivation as compared to nonadopters. Per hectare gross and net income for zerotillage adopters were higher over non-adopters in the study area. Apparently after adoption of zero-tillage, carbon emission and use of irrigation water was reduced. It was concluded that zero-tillage technology is considered to be one of the green technology for wheat growing because it not only reduced cost of inputs used for wheat production but also saves environment by reducing carbon emission and irrigation water use.

Among the different constraints associated with adoption of zero-tillage was non-availability of zerotillage machine on hiring basis and on time was identified as major problem in the study area. Therefore, government should encourage farmers to adopt zero-tillage for sowing wheat crop by providing subsidy on the zero-tillage machine. It will insure the timely availability of zero-tillage machine in the study area resulting into lower charges of zero-tillage machine. Government should also provide motivational training programme to the farmers for adopt green technology. Due to reduction in diesel consumption for ploughing, land levelling and sowing will ultimately reduce the substantial amount of foreign exchange by reducing the import of petroleum product i.e. diesel.

\section{Conflict of interest statement}

Authors declare that they have no conflict of interest.

\section{Acknowledgement}

Authors are thankful to UP Council of Agricultural Research (UPCAR), Lucknow for providing research grant to carryout research project on "Economic and Environmental Benefits of Resource Conservation Technologies in Different Agro-climatic Zones of Uttar Pradesh, India.

\section{References}

Alston, J.M., Norton, G.W., Pardey, P.G., 1995. Science under Scarcity: Principles and Practice for Agricultural Research Evaluation and Priority Setting. Cornell University Press, Ithaca.

Derpsch, R., 1998. Historical review of no tillage cultivation of crops, JIRCAS Working Report No. 13. pp.1-18.

Gentil, L.V., 1995. In: I seminario international do sistema plantio directo. Resumos. EMBRAPACNPT, Ponta Grossa, R S.Agosto. pp.9-12.

Jat, M.L., Sharma, S.K., Singh, K.K., 2006. Conservation agriculture for sustainable farming in India. Paper Presented in Winter School Training at Department of Agronomy, Tamil Nadu Agricultural University, Coimbatore.

Kumar, U., Gautam, U.S., Singh, S.S., Subhash, N., Singh, K., Kumar, R., 2005. Zero tillage technology in wheat cultivation, Proceedings of the Project Workshop on Accelerating the adoption of resource conservation technologies in rice-wheat systems of the Indo-gangetic plains, Hisar, India. pp.239-244.

Laxmi, V., Erenstein, O., Gupta, R.K., 2007. Impact of Zero Tillage in India's Rice-Wheat Systems, CIMMYT and the Rice-Wheat Consortium for the Indo-Gangetic Plains, New Delhi, India. pp.1-32.

Mallada, G.S. 1992. Introduction to Econometrics. 2 ${ }^{\text {nd }}$ Edn., MacMillan Publishing Company, New York.

Meisner, C.A., 1992. Report of On Farm Survey of the Mymensingh Region and Tangail: Wheat Growers' Practices, Perceptions and their Implications. Monograph No. 9, Bangladesh Agricultural Research Institute. Wheat Research Centre, Nashipur Dinajpur.

Meisner, C.A., 1996. Report of On Farm Survey of the Greater Comilla Region: Wheat Growers' Practices, Perceptions and their Implications. Monograph No. 13, Bangladesh 
Agricultural Research Institute. Wheat Research Centre, Nashipur Dinajpur.

Meisner, C.A., 1999. Report of On Farm Survey of the Greater Faridpur Region: Wheat Growers' Practices, Perceptions and their Implications. Monograph No. 14, Bangladesh Agricultural Research Institute. Wheat Research Centre, Nashipur Dinajpur.

Meisner, C. A., 2001. Environmental Impact of Resources Conservation Technology: The Case of Zero-Tillage in the Rice-Wheat System of South Asia. Report to the CGIAR Standing Panel on Impact Assessment Division of Agricultural Economics, Indian Agricultural Research Institute, New Delhi. pp.1-23.

Pal, S., Sekar, I., Kar, A., 2010. Environmental Impact of Resource Conservation Technology: The Case of ZeroTillage in the Rice-Wheat System of South Asia. Report to the CGIAR standing panel on impact assessment, Division of Agricultural Economics, Indian Agricultural Research Institute, New Delhi. pp.1-23.

Paustian, K., Antle, M., Sheehan, J., Eldor, P., 2006.
Agriculture's Role in Greenhouse Gas Mitigation. Pew Center on Global Climate Change, Washington, DC.

Saunders, D.A., 1990. Crop Management Research Summary of Results. WRC Monograph 5, Wheat Research Center Nashipur, Bangladesh.

Singh, K.M., Meena, M.S., 2013. Economics of Conservation Agriculture: An Overview. Munich Personal RePEc Archive. pp.1-18.

Singh, N.P., Singh, R.P., Kumar, R., Vashist, A.K., Khan, F., Varghese, N., 2011. Adoption of resource conservation technologies in Indo-gangetic plains of India: scouting for profitability and efficiency. Agric. Econ. Res. Rev. 24 (1), 15-24.

Singh, U.P., Singh, Y., Singh, H.P., Gupta, R.K., 2005. Cropping system options in no/reduced till - surface residue managed systems. In: Conservation Agriculture: Status and Prospects (Eds.: Abrol, I.P., Gupta, R.K., Malik, R.K.). Centre for Advancement of Sustainable Agriculture, National Agricultural Science Center (NASC) Complex, New Delhi. pp.79-85.

\section{How to cite this article:}

Singh, O. P., Singh, R., Lakra, K., Singh, P.K., 2016. Improving environmental and economic benefits through zero-tillage in Mirzapur district of Uttar Pradesh, India. Int. J. Curr. Res. Biosci. Plant Biol. 3(9), 89-96. doi: http://dx.doi.org/10.20546/ijcrbp.2016.309.013 